\title{
Impact of Wife Battering on the Family
}

\author{
Saif-ur-Rehman Saif Abbasi ${ }^{1}$
}

Email: Saif_abbasi2002@yahoo.com

\section{Muhammad Babar Akram¹}

drmbabar@gmail.com

\begin{abstract}
Bushra Manzoor ${ }^{2}$
1Department of Sociology, International Islamic University, Islamabad 2Department of Rural Sociology, University of Agriculture, Faisalabad
\end{abstract}

Doi:10.5901/mjss.2015.v6n4s1p344

\begin{abstract}
Wife battering is a common phenomenon in developing countries especially in South Asia. Pakistan is no exception to this social phenomenon and especially in rural areas wife battering is common and accepted as norm to legitimize the domination of masculinity. To explore this social phenomenon, a study was conducted in the rural areas of District Toba Tek Singh of Province Punjab. Data was collected from the married women through a pre-designed interview schedule. More than half of the respondents were illiterate and married to blood relatives, mostly with first cousin. Low participation in decision making, female subordination and wife battering was a common phenomenon. Husband desire to dominate, instigation of in-laws, and husband addiction appeared to be the major reasons behind wife battering in the study area. Battering caused many psychological problems such as psychological stress, fear and humiliation in the entire family. The children who experienced the beating of their mother developed aggressive attitude and also turned into delinquents. Establishment of family counseling centers, involvement of print and electronic media to highlight influence of family violence against women through panel discussion involving victims, sociologist, psychologists and community leader will be fruitful to change the attitude towards spousal violence and violence against women.
\end{abstract}

Keywords: Wife battering, domestic violence, aggressive behavior

\section{Introduction}

Violence pervades in women life and exists in many forms, sometime in public and many times behind closed doors. Wife battering mostly occurs in a closed door within family and almost always leads to crises. It is actually a manifestation of unequal power relations between men and women that started centuries back and still exists in many forms both in developing and developed societies with more cruel forms in former than the later. It is evident in all social classes, ethnic groups and communities (Mckie, 2005). Family which is an important source of life, care and emotional support turns into a place of violence. It starts with difference of opinion on petty matters and if the situation goes on worsening, the emotions of hate and anger can lead to violence and may finally ends up in separation or dissolution of marriage. Wife battering has been defined as "a woman who had received deliberate severe and repeated demonstrable physical injury from her husband" (Gayford, 1975).

This type of battering continues to be a global epidemic that kills, or tortures the female partner physically, psychologically, sexually and economically. It is one of the most pervasive forms of human rights violations, denying women and girls' equality, security, dignity, self-worth, and their right to enjoy fundamental freedom. Women and children are often in great danger at a place other than home and consider themselves safe within their families. But unfortunately, the safe heaven is increasingly turning into unsafe place where women face a regime of terror and violence at the hands of somebody close to them and somebody they trust. Their human rights are denied and lives are stolen from them by the ever presence threat of violence (UNICEF, 2000). As such violence mostly occurs in privacy in basic unit of socialization, so it becomes essential to throw some light on it in the domestic sphere. 


\subsection{Domestic Violence}

Violence against women cuts across all racial, social, cultural, economic, political and religious spectrums. Often it is perpetrated by those whom they have been encouraged to trust and respect, and those whom they love. Studies have shown that in many countries, one quarter to more than half of the women report having been physically abused by a current or a former partner. Goldberg (1999) reported that most physical violence between spouses involves the husbands hurting his wife whereas women most often involved in verbal exchange of words instead of using physical force. Violent couples abuse children, who in turn try to abuse each other. They become abusive adults and exhibit aggressive behaviour when form a family. Empirical evidences state that a large percentage of physically abusive parents were themselves abused by their own parents when they were kids (Silver, Dublin and Lourie, 1969; Strauss \& Gelles, 1980).

\subsection{Domestic Violence in South Asia}

Violence on women in Bangladesh, India, Nepal, Pakistan, and Sri-Lanka exists in various forms. However, the domestic violence is present in more or less in the shapes i.e. wife battering and stove burning in South Asian counties (Hayward, 1997). The prevalence of centuries old patriarchal norms (Smith, 1990), values, traditions and customs promoted gender inequality and its gradual legitimization of unequal power relation between men and women in all spheres of life including family (McCloskey et al., 2004; Yodanis 2004). Through a gradual process of socialization starting from childhood, females are prepared to internalize their inferiority and hegemony of males and this process continues even in adulthood. In these societies wife battering is widely condoned and tolerated by promoting a culture of silence.

\subsection{Situation in Pakistan}

In Pakistan, women are not only subjected to financial discrimination, but they are also victims of inhuman customs and laws such as Karo Kari and Marriage with the Quran (Niaz, 2006). Similarly, the phenomenon of wife battering is so common that it is not even considered as pernicious form of violence against women. Even in some cases where women receive serious injuries and want to file complaints, they are advised by their relatives as well as law agencies, especially the police to reconcile with their husbands, as the matrimonial dispute would bring dishonor to them.

According to Hausmann et al. (2011) Pakistan is placed at $133^{\text {th }}$ position out of the 135 countries. This statistic is also highlighted in a report which indicated that four out of five women face some sort of domestic violence in Pakistan (The Express Tribune, Dec. 11, 2013).

Keeping in view its significance, a micro level study was planned to explore this phenomena among communities living in rural areas, one of the District of the Punjab Province in the Central Punjab.

\subsection{Objectives}

$>$ To investigate the socio-economic factors associated with wife battering

$>$ To explore the impact of wife battering on family

$>$ Implication of social theories on domestic violence

\section{Theoretical Framework}

Various theories have been developed to explain the incidence of violence against women in family. Among these, the following three theories are very important and each one explains a different set of violent behaviour of husband and wife that leads to wife battering.

\subsection{The Learned Behaviour Theory}

It states that men who battered their wives have gradually learned this act in their families when they were growing as a child. Similarly, women who fall prey to such violence developed such attitude of bearing violence because they have learned it during their childhood when they frequently saw their mothers being abused by their fathers. Bandura and his associates (1961) explained the power of social learning theory (e.g. aggression) by observing others and imitating them. 


\subsection{Learned Helplessness Theory}

Walker (1977) who was a psychologist by profession hypothesized that women ignores the abusive relationship and gradually adapt to such environment as the continuous act of violence strips their will to leave the family. However, critics argued that a number of socioeconomic and cultural compulsions compel to stay in abusive home environment. This may include the future of children, her own disgrace and disgrace of her parents which serve as strong barrier to leave the spouse who commit successive act of violence.

\subsection{The Theory of Family/relationship Conflict}

Witt presented this model in 1987. This model explained that both men and women contribute to violence in family. Wife through below-the-belt argument provokes her spouse and receive a prompts response from husband in the form of violence. The frequent such behaviour build-up tension in the family until the male spouse explodes and become violent.

\subsection{Violence Wheel}

The Power and Control Wheel describes different types of tactics a man adopts during abusive behaviour to maintain his hegemony and reinforce his power over his partner. This wheel also helps in linking the different behaviors that together form a pattern of violence. It actually shows the relationship as a whole-and how each seemingly unrelated behavior is an important part in an overall effort to control someone.

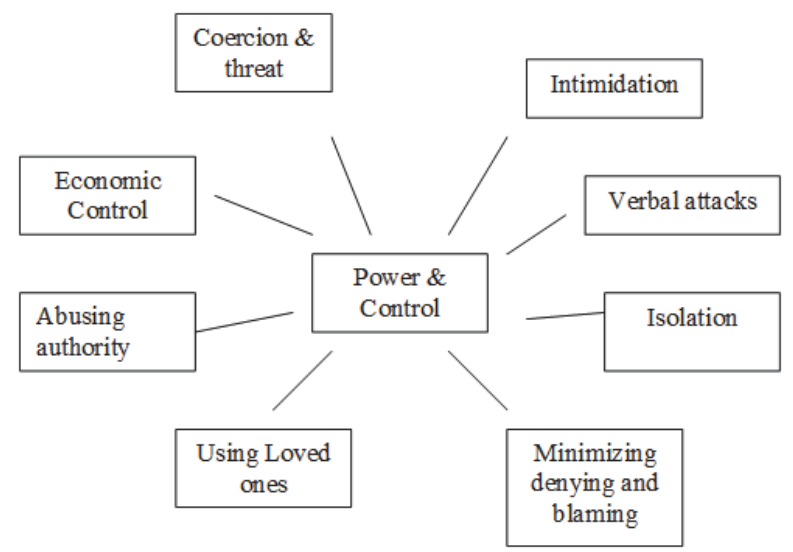

Source: Roberts (2006). Adopted from domestic abuse intervention project-Duluth-Minnesota)

\section{Materials and Methods}

This paper is based on primary data collected face to face interviews. Using a well designed interviewing schedule the survey was conducted in Union Council 45, District Toba Tek Singh which comprises six villages. Using the proportionate sampling technique a sample of 100 households was randomly selected from the universe of the study and one married woman from each household was interviewed. The data was analyzed by using the descriptive and inferential statistics. Different statistical tests were used to explore the relationship between the independent and dependent variables.

\section{Results and Discussion}

\subsection{Socio-economic characteristics of the respondents}

Table 4.1 reveals that $31 \%$ of the respondents belonged to the age group of $26-35$ years of age, while very low percentage was present in higher age category. As regards their educational attainments, $55 \%$ of the respondents were 
illiterate, $30 \%$ had up to 9 years of educational attainment and 15\% of them had matric and above level of education, 10 years of schooling or more. This shows that most of the respondents were illiterate or had low level of education. Similarly, a major proportion (44\%) of the respondent's husbands were illiterate, one fourth of them were less than matric and $31 \%$ were Matric and above. The question concerning the profession of the respondent's husbands revealed that 56 , 28, 9 and 7\% were farmers, laborers, government service, and engaged in business related activities respectively. As the survey was conducted in the rural area where most of the husbands of the respondents were farmers and laborers, the family income of the majority fall in lower income group. $38 \%$ of the respondents were having monthly income of less than Rs 2500 followed by $39 \%$ who had their monthly income between $2601-5000$ rupees while $23 \%$ were earning monthly income more than 5000 rupees. It clearly reflects that $77 \%$ of the families were earning less than Rs.5000 per month. About $38 \%$ of the respondents were living in nuclear families, while majority (62\%) was maintaining join family system. Majority of the respondents (66\%) had less than 11 years duration of marriage, $24 \%$ spent $11-20$ years of their married life and the remaining $10 \%$ had passed more than 20 years of their matrimonial life. The data on family size revealed that $30 \%$ of the respondents had $1-2$ children, while major proportion (49\%) of the respondents had $3-4$ children and $21 \%$ of them had 5 and above children. It means that majority were having middle size family. The results are not in line with the earlier studies wherein large family size was reported in rural areas having more than four children. However, going through the information on family size with age of the respondents in the same table, this confusion is cleared. Majority of the women were young and were likely to bear more children by the time they reach their menopause.

Table 4.1. Socio-economic characteristics of the respondents $(n=100)$

\begin{tabular}{|c|c|}
\hline Age (in years) & Percentage \\
\hline $19-25$ & 31 \\
\hline $26-35$ & 49 \\
\hline $36+$ above & 20 \\
\hline \multicolumn{2}{|l|}{ Educational Status } \\
\hline Illiterate & 55 \\
\hline Under matriculation (1-9 years of schooling) & 30 \\
\hline Matric and above (10+ years) & 15 \\
\hline \multicolumn{2}{|l|}{ Husband's Educational Status } \\
\hline Illiterate & 44 \\
\hline Less than matric (1-9 years of schooling) & 25 \\
\hline Matric and above (10+ years) & 31 \\
\hline \multicolumn{2}{|l|}{ Husband's Occupation } \\
\hline Labourer & 28 \\
\hline Farmer & 56 \\
\hline Govt. Service & 09 \\
\hline Business & 07 \\
\hline \multicolumn{2}{|l|}{ Monthly Family Income (Rs.) } \\
\hline Bellow 2500 & 38 \\
\hline $2601-5000$ & 39 \\
\hline 5001and above & 23 \\
\hline \multicolumn{2}{|l|}{ Family Type } \\
\hline Joint & 62 \\
\hline Nuclear & 38 \\
\hline \multicolumn{2}{|l|}{ Duration of Marriage } \\
\hline Less than 11 years & 66 \\
\hline $11-20$ years & 24 \\
\hline Above 20 years & 10 \\
\hline \multicolumn{2}{|l|}{ Family Size (No. of Children) } \\
\hline $1-2$ & 30 \\
\hline 3-4 & 49 \\
\hline Above 4 & 21 \\
\hline
\end{tabular}

\subsection{Women relationship with In-laws}

Woman relationship with her in-laws is vitally important in understanding their family life. This information is quite helpful 
in evaluating and linking the results of any empirical study on the subject. The table under discussion reveals that $63 \%$ of the respondents reported that their mother-in-law interfered with their personal matters, $59 \%$ blamed their sisters-in-law for the violence by their husbands. This indicates that wife battering may be caused by the interference of mother in-law and sisters of the husband. Regarding status of overall relationship with in-laws, more than half $(55 \%)$ of the women reported good relations while $45 \%$ were not experiencing good terms with their in-laws. Here, the in laws include the parents, brothers and sisters of the respondents' husbands. About $43 \%$ of the respondents stated that members of their in-laws family incited their husbands for beating. This fact shows that along with other factor instigation of in-laws is also a main factor of wife batter in our society as $43 \%$ respondents got battered on the instigation of the in laws.

Table 4.2. Relation Regarding Behavior of the In-Laws $(n=100)$

\begin{tabular}{|c|c|}
\hline Issue & Percentage \\
\hline Interference From Mother In Law & 63 \\
\hline Yes & 37 \\
\hline No & 59 \\
\hline Interference From Sisters In Law & 35 \\
\hline Yes & 06 \\
\hline No & \\
\hline Did not have sisters in law & 55 \\
\hline Good relations with in laws & 45 \\
\hline Yes & \\
\hline No & 43 \\
\hline In laws incite on Battering & 57 \\
\hline Yes & \\
\hline No & 56 \\
\hline Satisfaction with relations regarding in laws & 44 \\
\hline Yes & \\
\hline No & \\
\hline
\end{tabular}

\subsection{Relationship and Husband's Attitude}

The information in Table 4.3 shows that about two third of the respondents got married with their cousins while one third were married outside family with family friends, colleagues or among acquainted one. This shows that the tradition of marriage within family is very strong in Pakistani society. About $74 \%$ of respondents said that their husbands fulfill all the needs of family and $26 \%$ of them replied in negative. There is diversity regarding decision making about family matters; $17 \%$ of the respondents were free to decide all the matters, in 31\% cases only husband decide all the matters, in $22 \%$ cases there was a joint decision making by husband-wife and in 30\% cases other members of in laws hold the decision making powers. From the data it can be concluded that in $39 \%$ cases $(17+22)$ wife was involved in decision making about family while in $61 \%$ cases she was not involved. During field survey, the information whether their husbands were involved in any kind of addiction or not were also collected. The table further shows that husbands of $27 \%$ of the respondents were taking some kind of drug. Drug addiction and particularly low family income could be one of the causes of wife battering. Just $15 \%$ of the respondents said that their husbands treated them on the equal basis while a significant majority $(85 \%)$ said that husbands did not treat them equally. This element shows great subordination of women in society and especially in rural settings of Pakistan. Another surprising finding is that majority (73\%) of the respondents indicated that their husbands beat them even sometime on petty family matters. This shows that in rural areas where there is illiteracy and poverty wife battering is a common phenomenon. Moreover, in $65 \%$ cases husbands beat their wives just for domination.

Table 4.3. Relationship and Husband's Attitude ( $n=100)$

\begin{tabular}{|c|c|}
\hline Issues & Percentage \\
\hline Relations with Husband & 58 \\
\hline First cousins & 07 \\
\hline Second cousins & 23 \\
\hline Acquaintance & 12 \\
\hline No relation & \\
\hline
\end{tabular}




\begin{tabular}{|c|c|}
\hline Does he Fulfill all Needs? & 74 \\
\hline Yes & 26 \\
\hline No & 17 \\
\hline Decisions Making Status & 31 \\
\hline You & 22 \\
\hline Husband & 30 \\
\hline Both jointly & 27 \\
\hline In laws & 73 \\
\hline Yes & \\
\hline No & 15 \\
\hline Wife Equality & 85 \\
\hline Yes & 73 \\
\hline No & 27 \\
\hline Husband Beats & \\
\hline Yes & 65 \\
\hline No & 35 \\
\hline Husband Dominancy & \\
\hline Yes & \\
\hline No & \\
\hline
\end{tabular}

\subsection{Causes of Wife Battering}

The table 4.4 shows that wife battering was not caused by one factor. It was a multi-factorial phenomenon resulting from the instigation of in laws, low income and bad habits of husband. During interview, a question about the interest of their husbands in other women was also asked. About $17 \%$ of the respondents were of the view that their husbands used to take interest in other women as compared to $83 \%$ who denied the interest. In a male dominated society and especially in a rural setting, it is quite difficult to get real response to these sorts of questions.

Table 4.4. Causes of Battering $(n=100)$

\begin{tabular}{|c|c|}
\hline Causes of Wife Battering & Percentage \\
\hline Instigation of in laws & 47 \\
\hline Low income & 49 \\
\hline Habitual & 45 \\
\hline Drug use by husband & 27 \\
\hline Arguing of wife & 37 \\
\hline Husband does not like wife & 17 \\
\hline To dominate & 65 \\
\hline Husband does not beat & 28 \\
\hline Husband Interest in Other Woman \\
\hline Yes & 17 \\
\hline No & 83 \\
\hline \multicolumn{2}{|l}{} \\
\hline
\end{tabular}

\subsection{Physical and Psychological Effects of Wife Battering}

The data in Table 4.5 shows that $28 \%$ of the respondents had no quarrel with their husbands while $58 \%$ of the respondents faced simple physical beating, $5 \%$ had signs of beating and $9 \%$ had severe physical injury. There were many psychological effects of battering on the respondents. About $72 \%$ of the respondents said that they feel great threat due to the domination of their husbands and they always remain fearful. Owing to fear and domination of the husband and stress, $47 \%$ of the respondents lose their memory and generally forget necessary things. In case of difference of opinion of wife with husband, bickering and chiding results in battering. A very high majority (84\%) of the respondents said that they give verbal response in quarrel with the husband while $16 \%$ did not give verbal response and quietly listen and bear all sorts of mauling helplessly. From the sample respondents, 39\% said that they are fed up of their life due inhuman treatment of their life partners. In the rural areas of Punjab, the incidence of wife battering is common and accepted as norm that women began to immune of such treatment. The situation may be grasped from the statement of 
some illiterate women who consider it a sign of manhood of their husbands. Among them, some stated "O merd e key jaira marey na". (What type of man is he if he does not beat his wife) This is the reason that $23 \%$ of the respondents said that they feel relief after battering, however majority (77\%) said they do not have any such feelings. In our society when a girl is married her parents advise her at the time of her departure with her bridegroom by saying "putar hun tera janaza e ais ghar wichoun nickley" (Now you should not leave your husband house until you are alive).

That is why the girl after marriage has to resign to her fate whether she is willing to do so or not. This fact was clear from the present research as $61 \%$ of the respondents said that they were resigned to their fate while $39 \%$ said no. Owing to our social norms a woman after marriage has to adjust herself in the new setting of the family. That is why $53 \%$ of the respondents said that they feel helpless in this situation while $47 \%$ did not feel helpless. Not only wife but the whole family is affected from battering. It is the children who suffer the most. There are significant effects of battering on children.

Table 4.5. Physical and Psychological Effects of Wife Battering $(n=100)$

\begin{tabular}{|c|c|}
\hline Effects & Percentage \\
\hline Physical Effect of Battering & 58 \\
\hline Simple browsing & 05 \\
\hline Signs of beating & 09 \\
\hline Sever physical injury & 28 \\
\hline No quarrel & 72 \\
\hline Feel Fear & 28 \\
\hline Yes & \multicolumn{2}{|l|}{} \\
\hline No & 53 \\
\hline Forget Necessary Things & 53 \\
\hline Yes & 84 \\
\hline No & 16 \\
\hline Give Verbal Response & 39 \\
\hline Yes & 61 \\
\hline No & 23 \\
\hline Feel fed up of Life & 77 \\
\hline Yes & 61 \\
\hline No & 39 \\
\hline Yeel relief After Battering & 53 \\
\hline No & 47 \\
\hline Resigned on Fate & \\
\hline Yes & \\
\hline No & \\
\hline Feel Helpless & \\
\hline Yes & \\
\hline No & \\
\hline \multicolumn{2}{|l|}{} \\
\hline
\end{tabular}

\subsection{Effects of Battering on Children}

Socialization of the children is negatively affected; when the sons see their father beating their mother they show rude behaviour to their sisters and feel themselves dominant sex. This fact also surfaced during the analysis of the data in the present research wherein $59 \%$ of the respondents said that their sons showed rude behaviour while $41 \%$ said that their sons did not show rude behaviour. These $41 \%$ of the respondents were mostly from those families where wife battering was a rare phenomenon. On the other hand the girls when see their mother being beaten by their father become shy and fearful from males within as well as outside families. It is due to the fact that they frequently observe their mother submitting to their father. This fact was also found in the present study as $85 \%$ of the respondents said that their daughters were shy while just $15 \%$ said that their daughters were not shy while facing male members. On seeing mother being beaten by the father, children get emotionally disturbed due to attachment with mother.

This thing affects their physical growth and badly hurt their self-confidence. In the present study it was found that $43 \%$ of the respondents said that their children were physically weak, while $57 \%$ said no. Father has a dominant role in 
the family in the set-up of our society. If father shows good and polite behaviour, the children follow and reflect similar type of behaviour. But if he does not show good behaviour, it negatively influence the children's socialization and the try to avoid their parents. A similar type of situation was found in the present study. As a high majority (87\%) of the respondents said that their children feel fear of their father's behaviour. Wife battering also causes delinquent behaviour among children as $71 \%$ of the respondents said their children show such behaviour.

Table 4.6. Effect of battering on Children $(n=100)$

\begin{tabular}{|c|c|}
\hline Effects on Children & Percentage \\
\hline Boys are rude & 59 \\
\hline Yes & 41 \\
\hline No & \\
\hline Daughters are shy & 85 \\
\hline Yes & 15 \\
\hline No & \\
\hline Children are physically weak & 43 \\
\hline Yes & 57 \\
\hline No & 87 \\
\hline Children feel fear of their father's behavior & 13 \\
\hline Yes & \\
\hline No & 71 \\
\hline Children show delinquent behavior & 29 \\
\hline Yes & \\
\hline No & \\
\hline
\end{tabular}

\subsection{Testing of Hypothesis}

\subsubsection{Relationship between education of the respondents and after battering injury}

Table 4.7 shows that extent of wife battering increased with her education level indicating that higher the educational level, lower the element of battering. The data clearly indicates that only $14.5 \%$ illiterate respondents had no quarrel with their husbands as compared to $75 \%$ educated respondents with no quarrel with their husbands. Similarly, injury related to simple beating and with permanent sign decreased with increasing educational level and no such incidence is reported by the respondents with middle and above level of education. The chi-square value shows a highly significant association between education of the respondents and after quarrel injury with their husbands. The gamma value shows a strong negative relationship between the variables. This confirms our study hypothesis seeking support from data that uneducated women faced physical thrash from their husband.

The theories discussed in the earlier section of the paper improve the human understanding of why violence against women happens and how battering is used to maintain control and power over the victims. The dominant position of men, their economic authority and the subordinate positions of women due to their economic dependence and caring role promote the centuries old tradition of unequal power relationships between them. The current research suggests that a single theory cannot be used to explain the domestic violence on women. The witnessing of violence in childhood promotes the superiority of boy and submissiveness of girl and it strengthen with the passage of time as indicated in learned behaviour theory. Subsequently on becoming husband, he uses power to ensure the submissiveness of his wife. The helplessness of women and the compulsions from parents and in-laws family as well as fear of society further perpetuate their subordination as the helplessness theory states. The current study also supports that provocation of wife through below the belt arguments leads to domestic violence on women and the same is indicated by the theories based on mutual violence.

Hi: Wife battering injury is associated with Illiteracy.

Ho: Wife battering injury is not associated with Illiteracy. 
Table 4.7. Association between Low Education and Battering $(n=100)$

\begin{tabular}{|c|c|c|c|c|}
\hline \multirow{2}{*}{ Education } & \multicolumn{3}{|c|}{ After quarrelling injury } & \multirow{2}{*}{ Total } \\
\hline & No quarrel & Simple & Signs of beating and physical injury & \\
\hline Illiterate & 14.5 & 67.3 & 18.2 & 55.0 \\
\hline Primary & 20.0 & 64.0 & 16.0 & 25.0 \\
\hline Middle and above & 75.0 & 25.0 & - & 20.0 \\
\hline Total & 28.0 & 58.0 & 14.0 & 100.0 \\
\hline
\end{tabular}

\section{Conclusion}

With-in the broad purview of violence against women the phenomenon of wife battering has been most pervasive and is a major violation of human rights in Pakistan. It is very difficult to assess the extent of the problem in Pakistani society due to the strong notion of the privacy of the family. Low level of education of wife and husband, cousin marriage, instigation of the in-laws, drug addiction of the husband and verbal response of wife during quarrel are found to be the causes of battering and the findings regarding the effect of battering on family were found in two elements of the family, wife and children. The effects of battering on wives in Pakistani society includes; physical injury, feeling of fear and psychological stress that caused loss of memory, feeling of helplessness and feeling of being fed up with life. As regards the effects of battering on children, socialization of the children is affected negatively which makes them rude and develop delinquent habits. These children totally lack self-confidence due to permanent feeling of fear of father.

\section{Recommendations}

To change the male attitude towards female, and especially towards mother and girl child, some of the following measures can help improve the situation;

- establishment of family counseling centers

- attitudinal changes should be brought about through the involvement of print and electronic media to highlight influence of family violence against women through panel discussion involving victims, sociologists, psychologists and community leaders. entertainment programmes like short and long plays can also serve as effective measures to influence the attitude of males towards females.

- basic skill development centers to enable female participation in economic activities and share the family financial burden will improve their position in family and community which also act as barrier against domestic violence, especially in rural areas.

\section{References}

Bandura, Albert, Dorothea Ross, and Sheila A. Ross. (1961). Transmission of aggression through imitation of aggressive models. The Journal of Abnormal and Social Psychology 63,575.

Gayford, J. J. (1975). Wife Battering: A Preliminary Survey of 100 Cases. British Medical Journal, 1, 194.

Goldberg, C. (1999). National Desk. Spouse Abuse Crackdown, Surprisingly, Nets Many Women. New York Times, November, 23.

Hayward, R. F. (1997). Needed: A New Model of Masculinity to Stop Violence Against Girls and Women. UNICEF Regional Office for South Asia.

Hausmann, R., Tyson, L. D., \& Zahidi, S. (2011). The global gender gap report 2011. In World Economic Forum: Geneva.

Mckie, Linda, (2005). Families, Violence and Social Change. Open University Press, McGraw Hill Education. Berkshire, England.

McCloskey, L. A., Williams, C., \& Larsen, U. (2005). Gender Inequality and Intimate Partner Violence among Women in Moshi, Tanzania. International family planning perspectives, 124-130.

Niaz, U., \& Hassan, S. (2006). Culture and Mental Health of Women in South-East Asia. World Psychiatry, 5, 118.

Roberts, P. (2006). Building bridges between the healthy marriage, responsible fatherhood, and domestic violence movements: Issues, concerns, and recommendations. Couples and Marriage Series Brief, 7.

Silver, L.B., Dublin, C.C. \&Lourie, R.S. (1969). Does Violence Breed Violence? Contributions from a study of the Child Abuse Syndrome. American Journal of Psychiatry, 126. 404-407.

Smith, M. D. (1990). Patriarchal Ideology and Wife Beating: A test of a feminist hypothesis. Violence and Victims, 5. 257-273.

Strauss, M.A. \& Gelles. R.J. (1980). Behind Closed Doors: Violence in the American Family. New York: Anchor/Doubleday.

The Express Tribune. (2013). Four in five women in Pakistan face some form of domestic abuse: Report retrieved from http://tribune. com.pk/story/125993/four-in-five-women-in-pakistan-face-some-form-of-domestic-abuse-report/ December $(11,2013)$ 
UNICEF, (2000). Domestic Violence against Women and Girls. Innocent. Digest No. 6(2000). Innocent Research Centre, Florence, Italy.

Walker, L. E. (1977). Battered Women and Learned Helplessness. Victimology .

Witt, D. D. (1987). A Conflict Theory of Family Violence. Journal of Family Violence, 2, 291-301.

Yodanis, C. L. (2004). Gender Inequality, Violence against Women, and Fear A Cross-National Test of the Feminist Theory of Violence Against Women. Journal of Interpersonal Violence, 19, 655-675. 